\title{
Cardiac protein kinase $C$ expression in two models of cardiac hypertrophy associated with an activated cardiac renin-angiotensin system: effects of experimental hyperthyroidism and genetic hypertension (the mRen-2 rat)
}

\author{
L G D Fryer, M J Holness, J B J Decock ${ }^{\mathbf{1}}$ and M C Sugden \\ Department of Biochemistry, Basic Medical Sciences, St Bartholomew's and the Royal London School of Medicine and Dentistry, Queen Mary and Westfield \\ College, Mile End Road, London E1 4NS, UK and ${ }^{1}$ Department of Cardiac Medicine, Imperial College School of Medicine at the National Heart and Lung \\ Institute, London SW3 6LY, UK \\ (Requests for offprints should be addressed to M C Sugden)
}

\begin{abstract}
There is evidence for a role of protein kinase $\mathrm{C}$ (PKC) in the development of cardiac hypertrophy. We examined the expression of individual PKC isoforms in the adult rat heart in two distinct, well-characterised in vivo models of cardiac hypertrophy associated with an activated cardiac renin-angiotensin system, namely experimental hyperthyroidism and the TGR(mRen 2$) 27$ rat. The cardiac expression of a range of $\mathrm{PKC}$ isoforms $(\mathrm{PKC}-\alpha, \mathrm{PKC}-\delta$, PKC $-\varepsilon$, PKC $-\gamma$, and PKC- 1 ) was examined by immunoblotting. Our work demonstrates that the expression of total cardiac $\mathrm{nPKC}-\delta$ and $\mathrm{nPKC}-\varepsilon$ relative to protein is
\end{abstract}

selectively and differentially modified in these models. A consistent up-regulation of $\mathrm{nPKC}-\delta$ in conjunction with overall down-regulation of $\mathrm{nPKC}-\varepsilon$ was observed in both models. The expression of other PKC isoforms was unaffected. The divergent responses of the expression of the two nPKC isoforms to an activated cardiac reninangiotensin system in vivo in adulthood suggest that these individual $\mathrm{nPKC}$ isoforms subserve specific roles in the response.

Journal of Endocrinology (1998) 158, 27-33

\section{Introduction}

Members of the protein kinase C (PKC) family are important for regulating cell growth and are intracellular signalling molecules for a variety of $\mathrm{Gq}$ protein-coupled receptor agonists acting through hydrolysis of membrane phosphatidylinositol 4,5-bisphosphate (reviewed by Nishizuka 1992, 1995). The PKC family contains three subfamilies differing in structure, regulatory properties and tissue distribution (Ono et al. 1988, Dekker \& Parker 1994, Sugden \& Bogoyevitch 1995). The conventional PKCs (cPKCs) $(\alpha, \beta \mathrm{I} / \mathrm{II}$ and $\gamma)$ are activated by calcium, phosphatidylserine and diacylglycerol (DAG)/phorbol esters. The novel PKCs (nPKCs) $(\delta, \varepsilon, \eta / \mathrm{L}$ and $\theta)$ are activated by phosphatidylserine and DAG/phorbol esters, but are insensitive to calcium. The atypical PKCs (aPKCs) $(\zeta, 1$, and the mouse homologue $\lambda$ ) are insensitive to DAG/phorbol esters and calcium (Nakanishi et al. 1993). PKC isoform switching occurs during development and, even in adulthood, the PKC isoform expression profile responds to environmental and hormonal stimuli. The $\mathrm{nPKC}$ isoforms $\mathrm{nPKC}-\delta$ and $\mathrm{nPKC}-\varepsilon$ predominate in normal adult rat heart, and the $\mathrm{Ca}^{2+}$-sensitive cPKC isoforms are not consistently detected (Bogoyevitch et al.
1993, Rybin \& Steinberg 1994, but see Rybin \& Steinberg 1997).

PKC has been implicated as a signalling molecule mediating cardiac hypertrophy (Housey et al. 1988, Dunnmon et al. 1990, Sei et al. 1991) and overexpression of certain PKC isoforms has been associated with cardiac hypertrophy and altered cardiac performance. For example, targeted overexpression of the PKC- $\beta$ isoform in hearts of transgenic mice results in left ventricular hypertrophy (LVH), cardiac myocyte necrosis and decreased left ventricular performance (Wakasaki et al. 1997). Pressure overload (aortic banding), another hypertrophic stimulus, also leads to re-expression of cPKC isoforms (Gu \& Bishop 1994), normally only abundant in the immature heart (Rybin \& Steinberg 1994, Clerk et al. 1995). In addition, there is also a selective quantitative increase in $\mathrm{nPKC}-\varepsilon$ (Gu \& Bishop 1994). However, the expression of $\mathrm{nPKC}-\delta$ is unchanged $(\mathrm{Gu} \&$ Bishop 1994), raising the possibility that overexpression of one or more of the nPKC isoforms normally found in the adult heart may influence myocyte growth and/or heart performance.

Factors evoking LVH and changes in cardiac performance in adulthood include increased sympathoadrenal tone 
and increased workload (Chien et al. 1991, Komuro \& Yazaki 1993). The effect of increased workload may be signalled by the autocrine, paracrine or juxtacrine release of vasoactive peptides, notably angiotensin II (Baker \& Aceto 1990, Schelling et al. 1991, Lee et al. 1993, Sadoshima \& Izumo 1993, Lip et al. 1994). The renin-angiotensin system contributes to hyperthyroidism-induced cardiac hypertrophy (Kobori et al. 1997) and RIAs and RT-PCR revealed increased cardiac levels of renin and angiotensin II and enhanced cardiac expression of renin mRNA in hyperthyroid rats, with regression of LVH in response to losartan treatment (Kobori et al. 1997). Similarly, significant expression of the Ren-2 gene leads to overproduction of angiotensin II in the hearts of hypertensive transgenic TGR(mRen2)27 rats (Bohm et al. 1995, Lee et al. 1995) and it appears that pathomorphological changes in the hypertrophied hearts of these transgenic animals occur secondary to an activated intracardiac renin-angiotensin system (Bohm et al. 1995, Lee et al. 1995).

The present study used antibodies generated against synthetic peptides derived from unique sequences of individual PKC isoforms to identify and compare the effects of an activated cardiac renin-angiotensin system induced by experimental hyperthyroidism (triiodothyronine $\left(\mathrm{T}_{3}\right)$ injection) or introduction of the mouse Ren-2 gene into the rat genome (the TGR (mRen2)27 transgenic rat) on the cardiac PKC isoform expression profile in adulthood. The study was restricted to measurement of $\mathrm{PKC}$ protein expression as our primary interest was in protein abundance, rather than the regulation of PKC mRNA expression or of PKC activity.

\section{Materials and Methods}

\section{Materials}

Radiochemicals, prestained molecular mass standards, enhanced chemiluminescence (ECL) Western blotting detection reagents, autoradiography film (Hyperfilm ECL), horseradish peroxidase-linked anti-mouse immunoglobulin and intensifying screens were from Amersham International, Amersham, Bucks, UK. SDS-PAGE reagents and reagents for protein assay (Bradford method) were from Bio-Rad (Hemel Hempstead, Herts, UK). Nitrocellulose $(0.45 \mathrm{~mm})$ was from Schleicher and Schuel (Dassal, Germany). Other laboratory chemicals were from Merck (Poole, Dorset, UK). Mouse monoclonal antipeptide antibodies against PKC $-\alpha,-\delta,-\varepsilon,-\gamma$, and -1 were from Transduction Laboratories (Lexington, KY, USA). Rabbit anti-PKC- $\delta$ and $-\varepsilon$ polyclonal antibodies were from Gibco BRL (Paisley, Scotland). Horseradish peroxidase-linked anti-rabbit immunoglobulin was from Sigma (Poole, Dorset, UK).

\section{Animals and hormone treatment}

Female Wistar rats (200-250 g) from Charles River, Margate, Kent, UK were given free access to food and water. Rats were made hyperthyroid by daily subcutaneous injection of $\mathrm{T}_{3}(100 \mathrm{mg} / 100 \mathrm{~g}$ body weight per day in 200 to $250 \mu \mathrm{l}$ ) for 3 days. This resulted in an approximately $40 \%$ increase in left ventricular mass over the treatment period (results not shown; see also Sugden et al. 1992). Control rats were injected with equivalent amounts of hormone solvent $(10 \mathrm{mM} \mathrm{NaOH} / 0 \cdot 03 \%$ BSA). Heterozygous female TGR(mRen2)27 rats (281 \pm $8 \mathrm{~g})$ and TGR(mRen2)27 transgene negative controls $(265 \pm 6 \mathrm{~g})$ were from the Hatter Institute, University College London and were transferred to Queen Mary and Westfield College 2-3 weeks before use. Hypertension in the TGR(mRen2)27 rats was verified by systolic blood pressure measurements (tail-cuff plesthysmography) from 5 to 12 weeks, over which period mean blood pressure increased from $127 \pm 4 \mathrm{mmHg}$ to $236 \pm 6 \mathrm{mmHg}$ $(P<0 \cdot 001)$. Mean blood pressure in transgene negative rats did not exceed $140 \mathrm{mmHg}$ (results not shown). Mean heart weights $(\mathrm{g} / 100 \mathrm{~g}$ body weight $)$ were $4 \cdot 40 \pm 0 \cdot 17$ $(n=6)$ and $3.07 \pm 0 \cdot 04 \quad(n=6)$ respectively in the TGR(mRen2)27 and transgene negative rats $(P<0 \cdot 001)$.

\section{Sample preparation}

Whole hearts were excised under anaesthesia and freezeclamped. For each animal, the entire frozen heart was ground under liquid nitrogen, and homogenised with five volumes of $20 \mathrm{mM}$ Tris $\mathrm{pH} 8 \cdot 0,137 \mathrm{mM} \mathrm{NaCl}, 2 \cdot 7 \mathrm{mM}$ $\mathrm{KCl}, 1 \mathrm{mM} \mathrm{CaCl} 2,10 \%$ glycerol, $1 \%$ Igepal, $0.5 \mathrm{mM}$ $\mathrm{Na}_{3} \mathrm{VO}_{4}, 0.2 \mathrm{mM}$ PMSF, $10 \mathrm{mg} / \mathrm{ml}$ leupeptin, $1.5 \mathrm{mg} /$ $\mathrm{ml}$ benzamidine, $50 \mathrm{mg} / \mathrm{ml}$ aprotinin, $50 \mathrm{mg} / \mathrm{ml}$ pepstatin A. The homogenates were placed on ice for $20 \mathrm{~min}$ and then microfuged at $10000 \mathrm{~g}$ for $20 \mathrm{~min}$ at $4{ }^{\circ} \mathrm{C}$ to pellet cell debris and connective tissue. The supernatant, representing the total cell extract, was used for immunoblotting. Protein concentrations were determined by the Bradford method (Bradford 1976).

\section{SDS-PAGE and immunoblotting}

The supernatants were prepared for SDS-PAGE by boiling for $5 \mathrm{~min}$ in Laemmli sample buffer containing 5\% 2 -mercaptoethanol. Protein aliquots $(40 \mu \mathrm{g})$ were loaded onto 7.5\% (w/v) acrylamide gels and subjected to SDSPAGE in a Bio-Rad Mini Protean gel apparatus. Protein was transferred electrophoretically to nitrocellulose membrane $(0.45 \mathrm{~mm})$ for $1 \mathrm{~h}$ at $100 \mathrm{~V}$ using a Bio-Rad Mini Protean transfer apparatus with $0 \cdot 01 \%(\mathrm{w} / \mathrm{v})$ SDS added to the transfer buffer. The nitrocellulose was blocked by incubation in $5 \%(\mathrm{w} / \mathrm{v})$ non-fat domestic milk powder ('Marvel') (or 3\% BSA for PKC- $\delta$ and $-\varepsilon$ polyclonal 
antibodies) dissolved in $20 \mathrm{mM}$ Tris, $150 \mathrm{mM} \mathrm{NaCl}, 0 \cdot 1 \%$ (v/v) Tween 20, pH 7.5 (TTBS) overnight at $4{ }^{\circ} \mathrm{C}$.

Blocking buffer was decanted and primary antibody, dissolved in blocking buffer at the recommended dilution, added and incubated at room temperature for $2 \mathrm{~h}$. Blots were washed in TTBS for $45 \mathrm{~min}$ with at least five changes of buffer. Horseradish peroxidase-linked second antibody diluted in blocking buffer was added (anti-mouse for monoclonal antibodies; anti-rabbit for polyclonal antibodies). Nitrocellulose was incubated for $2 \mathrm{~h}$ at room temperature with the secondary antibody. Following washing of the blots, protein bands were visualised using Amersham ECL reagents and exposure to Hyperfilm for between $30 \mathrm{~s}$ and $10 \mathrm{~min}$. Immunoblots were quantified by laser scanning densitometry.

\section{Statistical methods}

Results are presented as mean \pm s.E.M. Statistical significance was assessed using a two-tailed Student's $t$-test. $P<0 \cdot 05$ was taken to indicate statistical significance of differences between groups.

\section{Results}

PKC isoform expression in hearts from adult euthyroid and hyperthyroid rats

Using immunoblot analysis, we first examined PKC isoform expression in total heart extracts from control, euthyroid adult Wistar rats. An initial characterisation using competing antigenic peptides was performed to determine the specificity of the antibodies. Preliminary experiments established the specificity of immunoreactivity by the use of the appropriate competing peptide antigen $(2 \mu \mathrm{g} / \mathrm{ml})$. Several antibodies recognised more than one protein, but in each case PKC protein bands were identified by their specific reduction in immunoreactivity when competing peptide was included (results not shown). We detected bands corresponding in apparent molecular mass to the cPKC isoforms cPKC- $\alpha$ (apparent molecular mass, $82 \mathrm{kDa}$ ) and cPKC- $\gamma$ (apparent molecular mass, $80 \mathrm{kDa}$ ), the nPKC isoforms nPKC$\delta$ (apparent molecular mass, $78 \mathrm{kDa}$ ) and nPKC- $\varepsilon$ (apparent molecular mass, $90 \mathrm{kDa}$ ), and the aPKC isoform aPKC-1 (apparent molecular mass, $74 \mathrm{kDa}$ ) in extracts of hearts from adult euthyroid rats. Representative immunoblots are shown to the right of Fig. 1. The presence of $\mathrm{cPKC}-\alpha\left(\mathrm{Ca}^{2+}\right.$-dependent $)$ and the two $\mathrm{Ca}^{2+}$ independent PKC isoforms (nPKC- $\delta$ and $n P K C-\varepsilon$ ) in adult rat hearts is consistent with previous reports (Bogoyevitch et al. 1993, Rybin \& Steinberg 1994). Other PKC isoforms, including PKC- $\beta$, were not detected.

Although $\mathrm{T}_{3}$ suppresses immunodetectable cPKC- $\alpha$ in cultures of neonatal rat ventricular myocytes (Rybin \&
Steinberg 1996), the abundance (relative to protein) of cPKC $-\alpha$ in extracts of whole hearts was unchanged by experimental hyperthyroidism in vivo (Fig. 1, top panel). cPKC $-\gamma$ expression was also unchanged (Fig. 1, top panel). In contrast, $\mathrm{nPKC}-\delta$ expression (relative to protein) was almost doubled $(P<0 \cdot 01)$ in response to experimental hyperthyroidism in vivo, whereas the expression of PKC- $\varepsilon$ in hearts of hyperthyroid rats was almost halved $(P<0 \cdot 001)$ (Fig. 1, middle panel). Although there was a trend towards increased aPKC- 1 expression in the heart of hyperthyroid rats, this did not achieve statistical significance (Fig. 1, bottom panel).

\section{PKC isoform expression in hearts from TGR(mRen2)27 rats}

PKC isoform expression was determined in adult TGR(mRen2)27 rats and in transgene negative (Hanover Sprague-Dawley $\times$ Wistar-Kyoto) controls. Immunoblot analysis revealed the presence of PKC- $\alpha,-\gamma,-\delta,-\varepsilon$, and -1 in hearts from the transgene negative controls, as in hearts from Wistar rats. Representative immunoblots are shown to the right of Fig. 2. There were no statistically significant changes in expression of PKC isoforms PKC $-\alpha,-\gamma$ or -1 (relative to protein) in the hearts of TGR(mRen2)27 positive rats (Fig. 2, top and bottom panels). The abundance of $\mathrm{nPKC}-\delta$ (relative to protein) in hearts of TGR $(m R e n 2) 27$ rats was increased 2 -fold $(P<0 \cdot 01)$ relative to the transgene negative controls (Fig. 2, middle panel). In contrast, the relative expression of $n P K C-\varepsilon$ in hearts of TGR(mRen 2$) 27$ rats was only 70\% $(P<0 \cdot 05)$ of that of the controls (Fig. 2, middle panel).

\section{Discussion}

The major specific PKCs identified in the neonatal rat heart to date (Bogoyevitch et al. 1993, Puceat et al. 1994, Rybin \& Steinberg 1994) are the cPKC isoforms cPKC- $\alpha$ and $\mathrm{cPKC}-\beta$, the $\mathrm{nPKC}$ isoforms $\mathrm{nPKC}-\delta$ and $\mathrm{nPKC}-\varepsilon$, and aPKC- $\lambda$ (previously identified as the structurally highly homologous PKC- $\zeta$; Rybin et al. 1997). The expression of the $\left(\mathrm{Ca}^{2+}\right.$-sensitive) cPKC isoforms, $c \mathrm{PKC}-\alpha$ and $\mathrm{cPKC}-\beta$, and of the $\mathrm{nPKC}-\delta$ isoform is progressively down-regulated during the first 2 postnatal weeks (Rybin \& Steinberg 1994, Clerk et al. 1995), and recent studies have provided evidence for regulation of both PKC- $\alpha$ and $-\delta$ at the level of transcription during this developmental period (Rybin et al. 1997). In the present study, we were able to reproduce the developmental decline in cardiac cPKC- $\alpha$ expression previously reported to occur during late foetal and early neonatal development (Rybin \& Steinberg 1994, Clerk et al. 1995). In our hands, abundances (relative to protein) were $100 \pm 14 \quad(n=3)$, $64 \pm 7(n=3)$ and $22 \pm 7(n=3)$ in hearts of 20-day foetal, 4-day neonatal and adult hearts respectively. Although there is also a relatively modest (30\%) developmental 

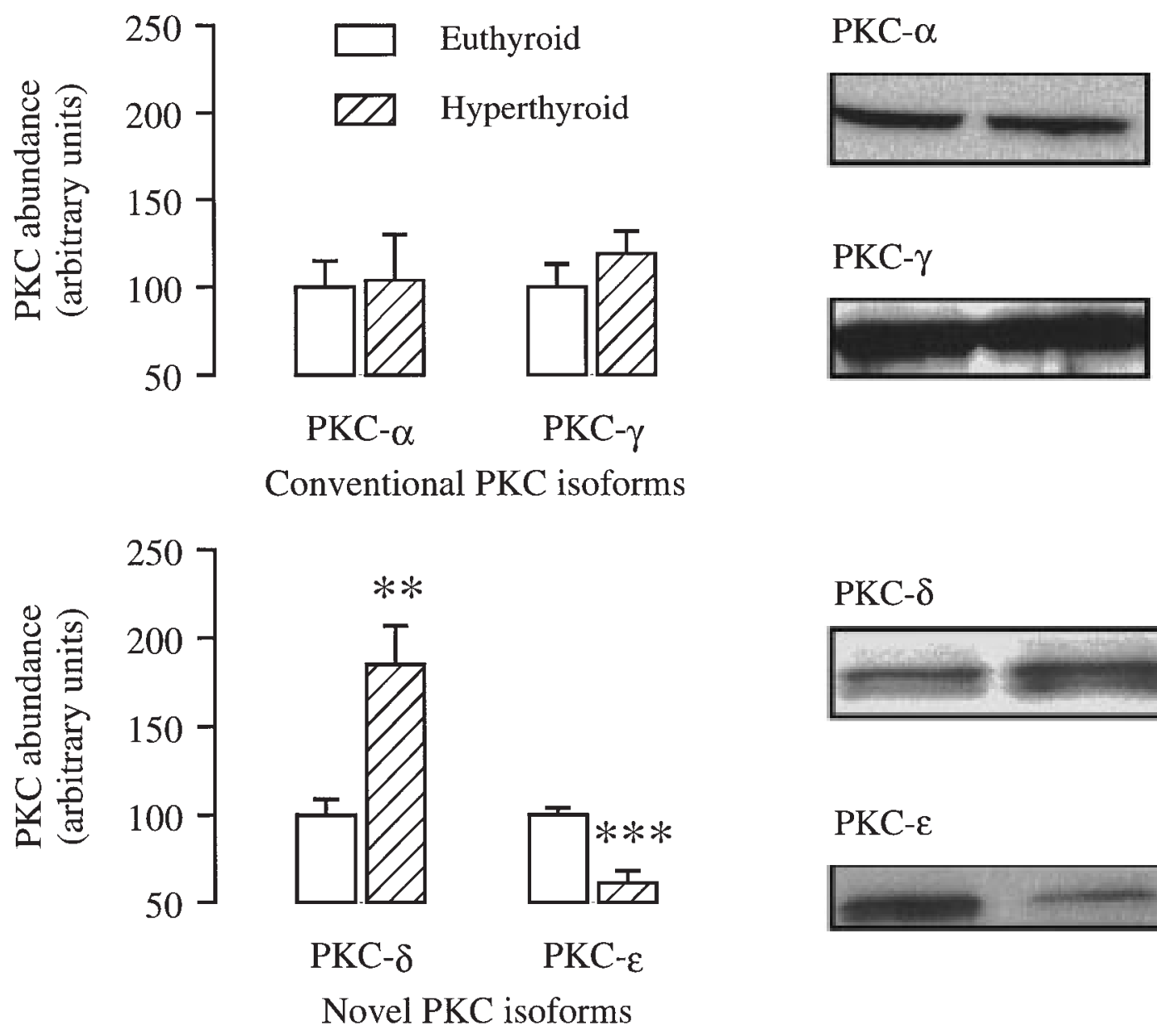

$\operatorname{PKC}-\delta$
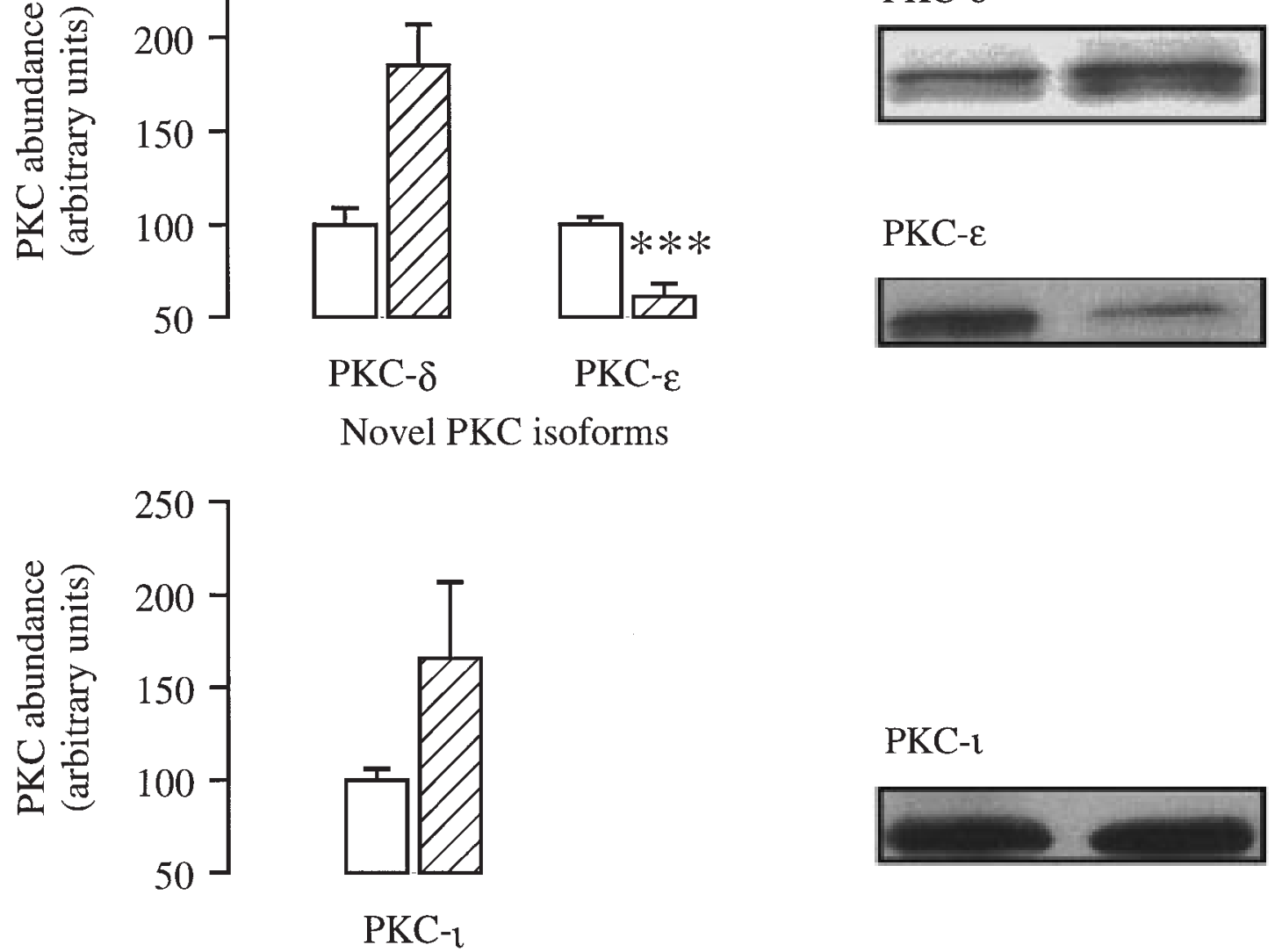

$\mathrm{PKC}-\varepsilon$

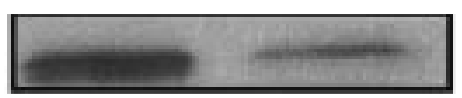

\section{PKC-1}

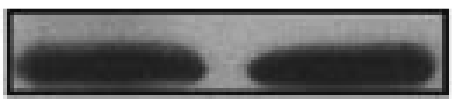

\section{Atypical PKC isoforms}

Figure 1 Quantification of PKC isoform expression in hearts from euthyroid and hyperthyroid rats. Total protein extracts from hearts were denatured and subjected to SDS-PAGE ( $40 \mu \mathrm{g}$ protein/lane) and immunoblotting with the isoform-specific antibodies indicated, as described in Materials and Methods. Results were analysed by laser densitometry. Results for hyperthyroid rats (three to eight per group) are expressed relative to PKC isoform expression in hearts from euthyroid rats when samples from euthyroid and hyperthyroid rats were run in parallel. Results for euthyroid rats are normalised to $100 \%$ and the S.E.M. for this group represents the variation observed between individual hearts (means for at least four rats). Data from representative single experiments (left hand blots, euthyroid; right hand blots, hyperthyroid) are shown to the right. 


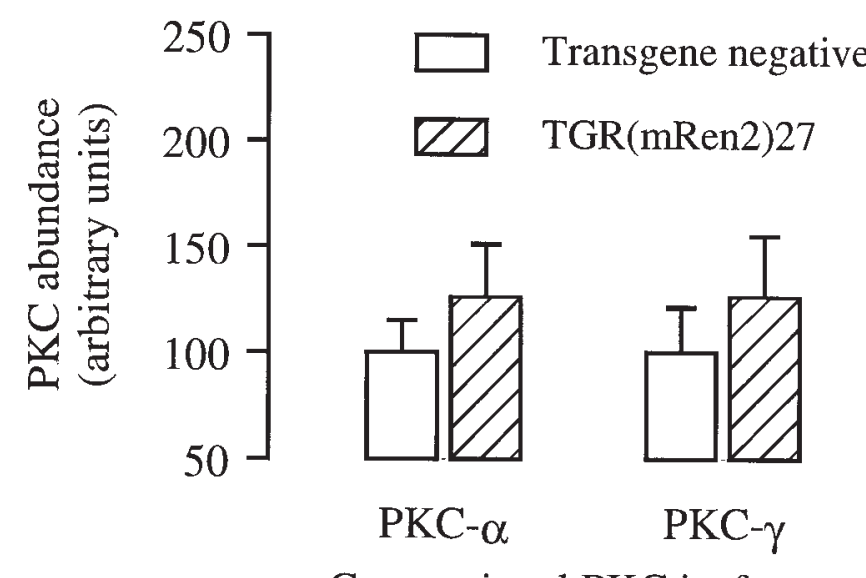

PKC- $\alpha$

\section{Conventional PKC isoforms}

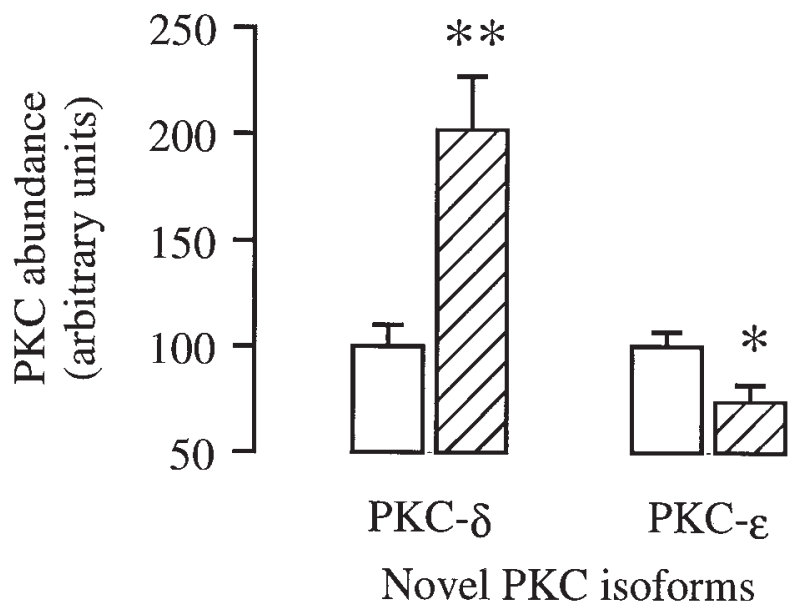

PKC- $\delta$

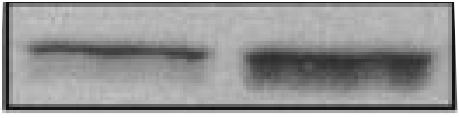

PKC- $\varepsilon$
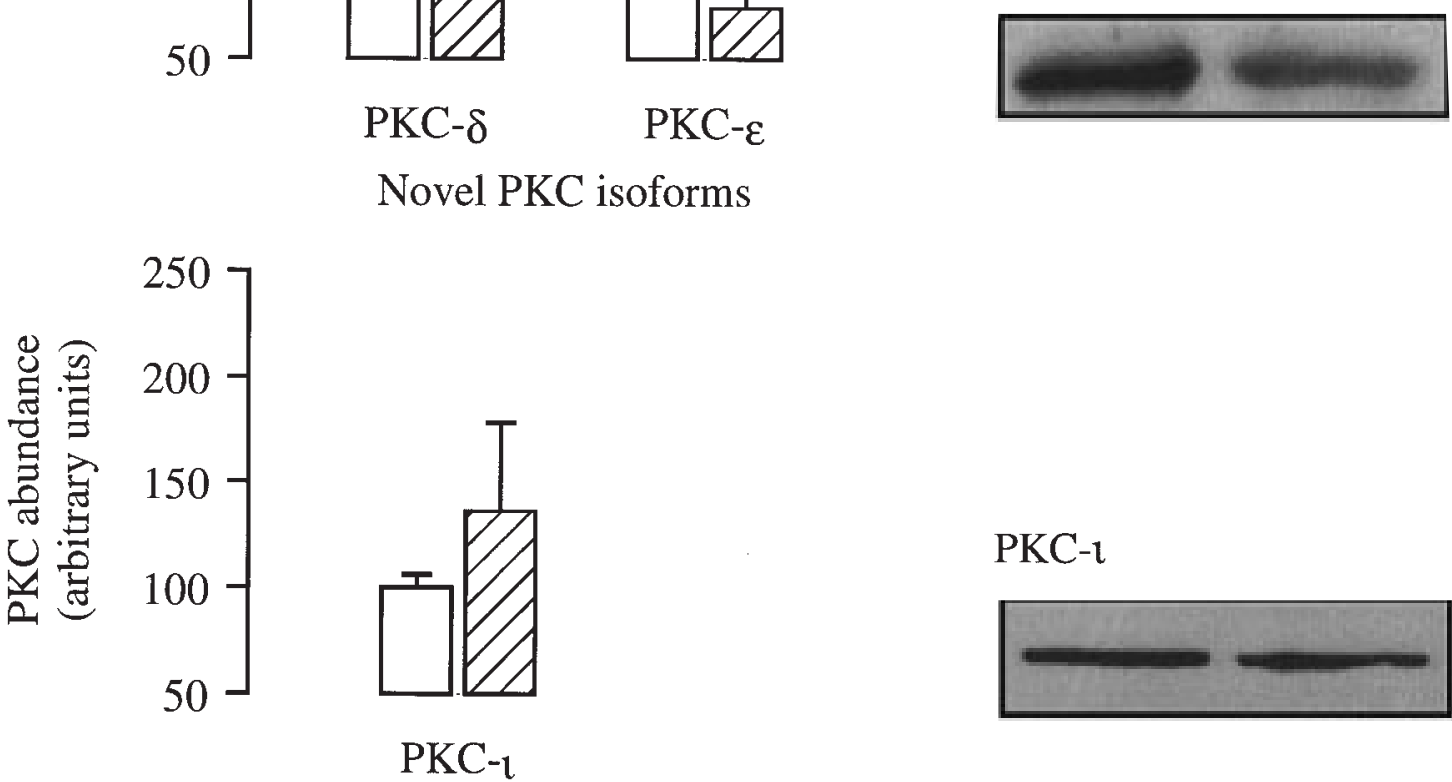

\section{Novel PKC isoforms}
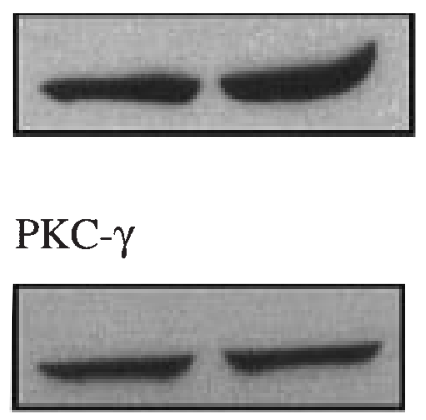

\section{PKC- $\gamma$}


decline in $\mathrm{nPKC}-\varepsilon$ expression, $\mathrm{nPKC}-\varepsilon$ continues to be expressed at high levels in adulthood (Rybin \& Steinberg 1994, 1996, Clerk et al. 1995). The developmental decline in expression of $\mathrm{cPKC}-\alpha$ and $\mathrm{nPKC}-\delta$ (Rybin \& Steinberg 1994, 1996) coincides with the maturation of the sympathetic innervation of the heart and a postnatal surge in thyroid hormone levels (see Rybin \& Steinberg 1996) and it has recently been established using cultured cardiac myocytes that the change in thyroid status could account for the down-regulation of $\mathrm{nPKC}-\varepsilon$ expression that occurs during normal cardiac development (Rybin \& Steinberg 1996).

The present study analysed the changes in expression of individual PKC isoforms in the adult rat heart induced by 3 days of experimental hyperthyroidism in vivo. The study is therefore of interest with respect to both the developmental influence of changes in thyroid status and the well-established actions of hyperthyroidism to activate the cardiac renin-angiotensin system (Kobori et al. 1997) and elicit LVH in adulthood (Litten et al. 1982, Chilian et al. 1985, Klein 1990). Our finding that $n P K C-\varepsilon$ protein expression is down-regulated in hearts of adult hyperthyroid rats complements previous results from Steinberg's group demonstrating increased $\mathrm{nPKC}-\varepsilon$ expression in hearts from adult hypothyroid rats (Rybin \& Steinberg 1996). The results provide clear evidence that the cardiac expression of $\mathrm{nPKC}-\varepsilon$ in the adult rat heart is responsive to changes in thyroid hormone status in vivo. In addition, we demonstrated up-regulation of cardiac $n \mathrm{nKC}-\delta$ protein expression in hearts of adult hyperthyroid rats. This response to elevated $\mathrm{T}_{3}$ levels in adulthood contrasts with down-regulation of $\mathrm{nPKC}-\delta$ during the neonatal period (Rybin \& Steinberg 1996). It therefore appears that down-regulation of cardiac $\mathrm{nPKC}-\varepsilon$ (as previously suggested by Rybin \& Steinberg 1996) is a consistent response to a rise in circulating thyroid hormone concentrations, but it is unlikely that neonatal down-regulation of $\mathrm{nPKC}-\delta$ is necessarily a consequence of increased thyroid hormone concentrations. It is not known to what extent the state of activation of the cardiac renin-angiotensin system is modulated by changes in thyroid status during developmental growth.

The TGR(mRen2)27 transgenic rat represents a noninvasive model for cardiac hypertrophy and hypertension with a clearly defined genetic alteration (Mullins et al. 1990, Bohm et al. 1995, Lee et al. 1995, Veniant et al. 1995). TGR(mRen2)27 rats develop severe fulminant hypertension $(200-260 \mathrm{mmHg}$ ) as a consequence of introduction of the mouse Ren-2 renin gene into the rat genome (Mullins et al. 1990). Pathomorphological alterations of cardiovascular organs, including an increased left ventricular mass index, are observed in young rats aged $<12$ weeks (Veniant et al. 1995) and have been attributed, at least in part, to an activated cardiac renin-angiotensin system (Bohm et al. 1995, Lee et al. 1995). The current studies demonstrate an approximately 2 -fold increase in cardiac $\mathrm{nPKC}-\delta$ expression relative to protein in adult TGR(mRen2)27 hypertensive rats compared with agematched transgene negative controls. There is a concomitant moderate decline in cardiac PKC- $\varepsilon$ expression, whereas the cardiac expression of the other PKC isoforms, including those mainly expressed during early development, is unchanged. Thus, as in hyperthyroidism, the cardiac isoform profile of the adult TGR(mRen2) 27 rat still contains mainly $\mathrm{nPKC}$ isoforms, but there is a switch towards the $n \mathrm{PKC}-\delta$ isoform at the expense of $\mathrm{nPKC}-\varepsilon$ in the absence of re-expression of cPKC isoforms.

In conclusion, we examined the protein expression of individual $\mathrm{PKC}$ isoforms in vivo in hearts of adult rats using two quite distinct models of LVH (experimental hyperthyroidism and genetic hypertension) associated with an activated cardiac renin-angiotensin system. Our work demonstrates that cardiac $n \mathrm{nKC}-\delta$ and $\mathrm{nPKC}-\varepsilon$ expression is selectively and differentially modified, and the responses are similar in the two models. The similarity between the effects of genetic hypertension and hyperthyroidism in altering the PKC isoform balance within a specific PKC isoform class (the $\mathrm{nPKCs}$ ) implies a common regulatory influence and strongly suggests that modulation of the cardiac PKC isoform profile is a specific response to an activated renin-angiotensin system. However, it should be emphasised that the findings of altered protein levels of these two important signalling molecules does not provide insight into the activation state of the enzymes, nor can conclusions be drawn as to whether enzyme levels change in response to increased activation. A consistent upregulation of cardiac $\mathrm{nPKC}-\delta$ was observed in conjunction with overall down-regulation of cardiac $n \mathrm{PKC}-\varepsilon$. The divergent responses of the two PKC isoforms argue in favour of the hypothesis that these individual nPKC isoforms subserve different roles in mediating the response to an activated renin-angiotensin system. It is notable that these two isoforms both belong to the novel sub-family of $\mathrm{PKC}$ isoforms, and that the reason for differences in their response can not be simply attributed to the sub-family to which they belong.

\section{Acknowledgements}

We are grateful for support from the Royal Society and the British Heart Foundation. We thank the Hatter Institute, University College London for provision of TGR(mRen2)27 rats and transgene negative controls, and for blood pressure measurements. J B J D holds a British Heart Foundation Studentship.

\section{References}

Baker KM \& Aceto JF 1990 Angiotensin II stimulation of protein synthesis and cell growth in chick heart cells. American Journal of Physiology 259 H610-H618. 
Bogoyevitch MA, Parker PJ \& Sugden PH 1993 Characterization of protein kinase $\mathrm{C}$ isotype expression in adult rat heart. Protein kinase $\mathrm{C}-\varepsilon$ is a major isotype present and it is activated by phorbol esters, epinephrine, and endothelin. Circulation Research 72 757-767.

Böhm M, Lee M, Kreutz R, Kim S, Schinke M, Djavidani B, Wagner J, Kaling M, Wienen W, Bader M \& Ganten D 1995 Angiotensin II receptor blockade in TGR(mRen2)27: effects of renin-angiotensin system gene expression and cardiovascular functions. Journal of Hypertension 13 891-899.

Bradford MM 1976 A rapid and sensitive method for the quantitation of microgram quantities of protein utilizing the principle of protein-dye binding. Analytical Biochemistry 72 248-254.

Chien KR, Knowlton KU, Zhu H \& Chien S 1991 Regulation of cardiac gene expression during myocardial growth and hypertrophy: molecular studies of an adaptive physiologic response. FASEB Journal 5 3037-3046.

Chilian WM, Wangler RD, Peters KG, Tomanek RJ \& Marcus ML 1985 Thyroxine-induced left ventricular hypertrophy in the rat. Anatomical and physiological evidence for angiogenesis. Circulation Research 57 591-598.

Clerk A, Bogoyevitch MA, Fuller SJ, Lazou A, Parker PJ \& Sugden PH 1995 Expression of protein kinase C isoforms during cardiac ventricular development in rat and man. American Journal of Physiology 269 H1087-H1097.

Dekker LV \& Parker PJ 1994 Protein kinase C - a question of specificity. Trends in Biochemical Science 19 73-77.

Dunnmon PM, Iwaki K, Henderson SA, Sen A \& Chien KR 1990 Phorbol esters induce immediate-early genes and activate cardiac gene transcription in neonatal rat myocardial cells. Journal of Molecular and Cellular Cardiology 22 901-910.

Gu X \& Bishop SP 1994 Increased protein kinase C and isozyme redistribution in pressure-overload cardiac hypertrophy in the rat. Circulation Research 75 926-931.

Housey GM, Johnson MD, Hsiao WLW, O’Brian CA, Murphy JP, Kirschmeier PT \& Weinstein IB 1988 Overproduction of protein kinase $\mathrm{C}$ causes disordered growth control in rat fibroblasts. Cell $\mathbf{5 2}$ 343-354.

Klein I 1990 Thyroid hormone and the cardiovascular system. American Journal of Medicine 88 631-637.

Kobori H, Ichihara A, Suzuki H, Takenaka T, Miyashita Y, Hayashi M \& Saruta T 1997 Role of the renin-angiotensin system in cardiac hypertrophy induced in rats by hyperthyroidism. American Journal of Physiology 273 H593-H599.

Komuro I \& Yazaki Y 1993 Control of cardiac gene expression by mechanical stress. Annual Review of Physiology 55 55-75.

Lee MA, Bohm M, Paul M \& Ganten D 1993 Tissue reninangiotensin systems: their role in cardiovascular disease. Circulation 87 (Suppl IV) 7-13.

Lee MA, Bohm M, Kim S, Bachmann S, Bachmann J, Bader M \& Ganten D 1995 Differential gene expression of renin and angiotensinogen in the TGR(mRen-2)27 transgenic rat. Hypertension 25 570-580.

Lip GYH, Gammage MD \& Beevers DG 1994 Hypertension and the heart. British Medical Bulletin 50 299-321.

Litten RZI, Martin BJ, Low RB \& Alpert NR 1982 Altered myosin isozyme patterns from pressure-overloaded and thyrotoxic hypertrophied rabbit hearts. Circulation Research 50 856-864.

Mullins JJ, Peters J \& Ganten D 1990 Fulminant hypertension in transgenic rats harbouring the mouse Ren-2 gene. Nature 344 $541-544$.
Nakanishi H, Brewer KA \& Exton JH 1993 Activation of the $\zeta$ isozyme of protein kinase $\mathrm{C}$ by phosphatidylinositol 3,4,5triphosphate. Journal of Biological Chemistry 268 13-16.

Nishizuka Y 1992 Intracellular signalling by hydrolysis of phospholipids and activation of protein kinase C. Science $\mathbf{2 5 8}$ 607-614.

Nishizuka Y 1995 Protein kinase C and lipid signaling for sustained cellular responses. FASEB Journal 97 484-496.

Ono Y, Fujii T, Ogita K, Kikkawa I \& Nishizuka Y 1988 The structure, expression, and properties of additional members of the protein kinase C family. Journal of Biological Chemistry 263 6927-6932.

Puceat M, Hilal-Dandan R, Strulovici B, Brunton LL \& Brown JH 1994 Differential regulation of protein kinase C isoforms in isolated neonatal and adult cardiomyocytes. Journal of Biological Chemistry 269 16938-16944.

Rybin VO \& Steinberg SF 1994 Protein kinase C isoform expression and regulation in the developing rat heart. Circulation Research $\mathbf{7 4}$ 299-309.

Rybin V \& Steinberg SF 1996 Thyroid hormone represses protein kinase $\mathrm{C}$ isoform expression and activity in rat cardiac myocytes. Circulation Research 79 388-398.

Rybin V \& Steinberg SF 1997 Do adult rat ventricular myocytes express protein kinase C- $\alpha$ ? American Journal of Physiology 272 H2485-H2491.

Rybin VO, Buttrick PM \& Steinberg SF 1997 PKC- $\lambda$ is the atypical protein kinase $\mathrm{C}$ isoform expressed by immature ventricle. American Journal of Physiology 272 H1636-H1642.

Sadoshima J \& Izumo S 1993 Molecular characterization of angiotensin II-induced hypertrophy of cardiac myocytes and hyperplasia of cardiac fibroblasts. Critical role of the AT1 receptor subtype. Circulation Research 73 413-423.

Schelling P, Fischer H \& Ganten D 1991 Angiotensin and cell growth: a link to cardiovascular hypertrophy? Journal of Hypertension 9 3-15.

Sei CA, Irons CE, Sprenkle AB, McDonough PM, Brown JH \& Glembotski CC 1991 The $\alpha$-adrenergic stimulation of atrial natriuretic factor expression in cardiac myocytes requires calcium influx, protein kinase C, and calmodulin-regulated pathways. Journal of Biological Chemistry 266 15910-15916.

Sugden MC, Holness MJ, Liu YL, Smith DM, Fryer LG \& Kruszynska YT 1992 Mechanisms regulating cardiac fuel selection in hyperthyroidism. Biochemical Journal 286 513-517.

Sugden PH \& Bogoyevitch MA 1995 Intracellular signalling through protein kinases in the heart. Cardiovascular Research 30 478-492.

Veniant M, Whitworth CE, Menard J, Sharp MG, Gonzales MF, Bruneval P \& Mullins JJ 1995 Developmental studies demonstrate age-dependent elevation of renin activity in TGR(mRen2)27 rats. American Journal of Hypertension 8 1167-1176.

Wakasaki H, Koya D, Schoen FJ, Jirousek MR, Ways DK, Hoit BD, Walsh RA \& King GL 1997 Targeted overexpression of protein kinase C $\beta 2$ isoformin myocardium causes cardiomyopathy. Proceedings of the National Academy of Sciences of the USA 94 9320-9325.

Received 24 November 1997

Revised manuscript received 21 January 1998 Accepted 24 February 1998 